Environment

\section{Baikal a symbol of Soviet intent}

THE most vivid illustration of the scale of Lake Baikal is the sight of the river Angara at Irkutsk, $60 \mathrm{~km}$ away from the point at which it is the only exit from this inland sea. The river is more than a kilometre wide at this point, and fast enough to cause trouble for the ferries that ply between the banks.

The lake itself is almost incomprehensibly huge. Standing on the Western shore on a clear day in late September with good visibility, one could see the peaks of the wall of rock rising from the eastern shore but not the roots, still hidden in the surface mist. At the exit of the Angara, the lake is more than $20 \mathrm{~km}$ across. Elsewhere, it is wider. The other two dimensions of Baikal are even more puzzling. The length, as any map will show, is more than $700 \mathrm{~km}$, but the depth reaches to $1,640 \mathrm{~m}$, making the lake the largest single body of fresh water on the surface of the Earth. The local estimate is that Baikal contains between a quarter and a third of the world's fresh water. The average flow of the Angara is merely enough to empty the lake once in 400 years.

The structure is evidently a rift valley. Chains of islands on transects of the lake mark the places where earlier mountain ranges have sunk with the rift floor, helping to divide the water circulation of the lake into three largely separate cells. On the face of things, the rift will break out to the sea on the shore of the Sea of Okhutsk, opposite the Kamchatka peninsula.

Estimates of Baikal's age, based largely on palaeontological data, are about 20 million years, but so little is known of the underlying tectonic processes that Baikal must be a happy hunting ground for geophysicists for many years to come.

Biologists' interests may be even more pointed, according to the newly appointed director of the Institute of Limnology at Irkutsk, Dr Mikhail Grachev. The baby seal at the University of Irkutsk's research station up the lake poses a problem: how does it come about than an inland lake supports freshwater adaptations of seawater mammals? There are 2,500 indigenous species in the lake, including bottomliving fishes adapted to the pressure of $1,600 \mathrm{~m}$ of water and sponges not very different from those best known in tropical seas. How did this diversity arise in a mere 20 million years?

But none of this is evident enough to give the lake its sense of magic. The approach to the place is more evocative. The road from Irkutsk, winding up the right bank of the Angara, first reaches a promontory $100 \mathrm{~m}$ above the sill over which the lake is emptied.

A kilometre further on, there is a hamlet of log-built Russian houses, with their

curiously projecting dovetail joints at the corners (and some modern equivalents being built of sawn $25-\mathrm{cm}$ timbers with corners that look the same) together with a working Orthodox church half-filled, on a Sunday evening, with local women. The lakeside road ends a further kilometre beyond, at a dock with a handful of research vessels. Beyond that, there is nothing to scar the shoreline, so that the steep cliffs, painted red and yellow as well as green for autumn, fall directly into the lake.

Communications around Lake Baikal are by the surface of the lake. In the summer, people use boats or even ships, in the

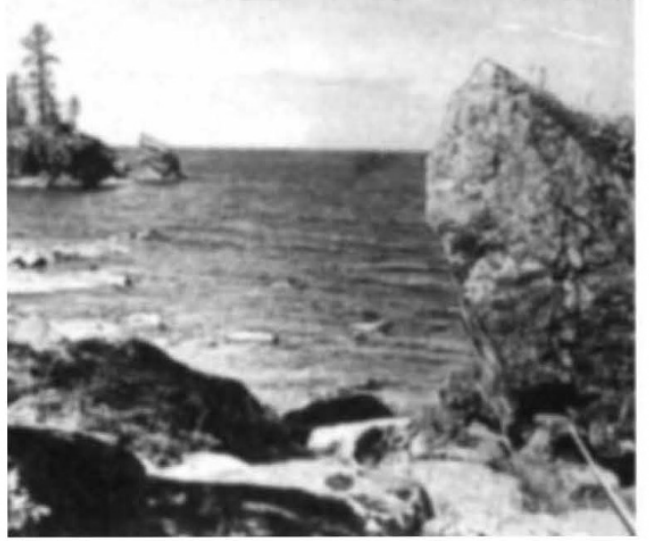

Baikal - a place of superlatives and extremes. winter, sledges or skis. A few kilometres north of the dock, there is a solar telescope operated by the Institute of Astrophysics at Irkutsk perched on a peak several hundred metres above the lake. Twenty $\mathrm{km}$ north of that is a research station belonging to the biology department of the University of Irkutsk.

In a cove marked by a series of shoreline pinnacles to the north, there is a comfortable wooden house and half a dozen uncomfortable huts, in one of which a research student is huddled over jars of larvae. A juvenile seal flops about in a shallow concrete pool, ostensibly in the cause of a test of visual cognition of which the best to be said is that it is uncontrolled.

Water quality has made Baikal a contemporary legend. You can tell how pure it is by looking at the pebbles $5 \mathrm{~m}$ down, at the edges of the lake. Grachev's group plans to use the most sensitive instruments they can find (or build) to establish a baseline with which later measurements can be compared. The purity of the water explains why the Ministry of Paper and Pulp Industries decided, more than a decade ago, to build two paper-pulp plants on the south-western bank, one on a tributary and the other on the lake itself. There has been moderate uproar ever since. At one stage, the late Peter Kapitza intervened in support of those who fear that the output

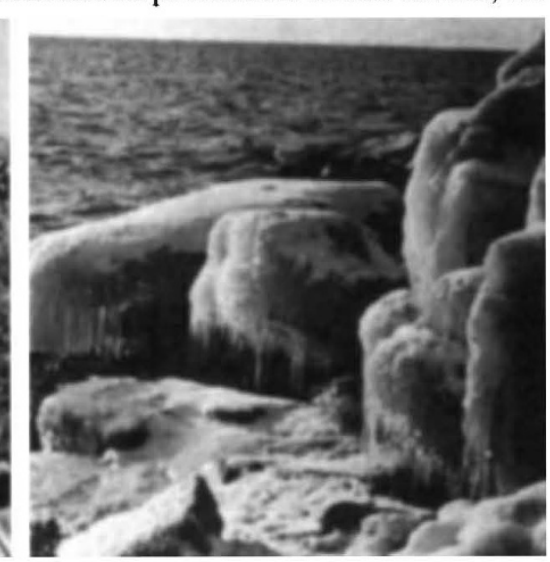

of $200,000 \mathrm{~m}^{3}$ a day of effluent from each of the two plants will eventually spoil the lake. Two years ago, the ministry agreed that both plants should be closed, but not until the labour-force moved from Western Russia to operate the plants had been retrained for making furniture.

People say that they were first alerted to the polluting potential of the pulp plants by the sophistication of the equipment for the treatment of the effluent. Quite what damage has been done so far is not yet clear, but a visiting Finnish group this summer is said to have evidence that dioxin is formed during the burning of chlorolignin practised at the two plants.

The saga of Baikal marks a turning point in Soviet opinions, especially the intelligensia's opinions, of the environment and its protection. In due course, the

movement will no doubt be recognized to have been part of an indirect protest at the intellectual bankruptcy of the Brezhnev era, and which has now made environmental integrity a goal akin to peace (by means of the abolition of nuclear weapons).

People talk of "our global heritage" and "our common problem", inviting all shoulders to help propel the same wheel. The same opinion-makers are oddly indifferent to the way that Brezhnev's (and even Khruschev's) suburban factories continue to pollute the air their people breathe.

But what about the pollution of Baikal's four-century stock of discharge for the Angara? Early on a sunlit September day, only the people with the sharpest vision claimed to spot the discharge from the chimney stacks the other side of the lake. But as the temperature fell, there was a curious phenomenon: one of several valleys on the other side began to fill with mist, a consequence, the knowledgeable said, of diffusive turbulence stimulated by the distant chimney stacks. Then two dark plumes of smoke appeared silhouetted against the mist, illuminated for an endless half-hour by the setting pre-winter sun. The sailing party, atheists to a man, went off to hear the singing at the Orthodox church. 